\title{
Produtos Notáveis e Emoções: uma análise de Práticas Matemáticas sob o viés dos Critérios de Idoneidade Didática
}

\author{
Luciana Correia de Amorim \\ Tânia Cristina Rocha Silva Gusmão \\ Sandra Maria Pinto Magina
}

\begin{abstract}
Resumo: Este artigo tem por objetivo apresentar um sistema de noções teóricas utilizadas para descrever, avaliar e comparar como duas professoras da Educação Básica, da rede pública e privada do município de Vitória da Conquista - Bahia, Brasil, direcionaram suas atenções às emoções em suas práticas matemáticas, quando trabalharam o mesmo conteúdo matemático: Produtos Notáveis. Dentro de uma abordagem qualitativa, a Observação Participante foi empregada como principal técnica de produção dos dados, auxiliada pelos instrumentos diário de campo e gravador de áudio. Ao estabelecer uma análise geral e comparativa entre as práticas observadas, à luz do referencial teórico dos Critérios de Idoneidade Didática (CID), verificamos que a professora que melhor atenção deu o Critério Afetivo, a partir do empreendimento de atividades motivadoras, teve, consequentemente, a elevação também dos demais Critérios de Idoneidade em sua prática matemática.
\end{abstract}

Palavras-chave: Emoções. Prática Matemática. Critérios de Idoneidade Didática. Produtos Notáveis.

Luciana Correia de Amorim Mestrado em Educação Científica e Formação de Professores pela Universidade Estadual do Sudeste da Bahia (UESB). Professora do Colégio da Polícia Militar Eraldo Tinoco, Vitória da Conquista, Bahia, Brasil.

https://orcid.org/0000-0002-6682-5131

$\triangle$ lucianamorim rc@hotmail.com .

Tânia Cristina Rocha Silva Gusmão Doutorado em Didática da Matemática pela Universidade de Santiago de Compostela (USC). Professora da Universidade Estadual do Sudoeste da Bahia (UESB), Vitória da Conquista, Bahia, Brasil. Professora Bolsista Produtividade da Capes $P Q-2$.

Dhttps://orcid.org/0000-0001-6253-0435 $\triangle$ professorataniagusmao@gmail.com

Sandra Maria Pinto Magina Doutorado em Mathematics Education. University of London, UL, Inglaterra. Professora da Universidade Estadual de Santa Cruz, UESC, Brasil. (UESC), Ilhéus, Bahia, Brasil. Professora Bolsista Produtividade da Capes PQ-2.

iD http://orcid.org/0000-0003-0383-9744

\. sandramagina@gmail.com

Recebido em 04/07/2021 Aceito em 08/09/2021 Publicado em 30/10/2021

\section{Binomial and Emotions: an analysis of Mathematical Practice from the perpective of Didactic Repute Criteria}

Abstract: This article aims to present a system of theoretical notions used to describe, evaluate and compare how two public and private Basic Education female teachers in the municipality of Vitória da Conquista - Bahia, Brazil, have directed their attention to emotions in their mathematical practices, when they had worked on the same mathematical content: Binomial. Within a qualitative approach, participant observation was used as the main data production technique, aided by field diary and audio recorder instruments. By establishing a general and comparative analysis between the observed practices, in the light of theoretical framework of Didactic Repute Criteria (DRC), we have found that the teacher who has given the best attention to the affective criterion, from the undertaking of motivating activities, had, consequently, the uplift of other criteria of suitability in his mathematical practice as well.

Keywords: Emotions. Mathematical Practice. Didactic Repute Criteria. Binomial.

\section{Productos notables y Emociones: un análisis de las Prácticas Matemáticas desde la perspectiva de los Criterios de Idoneidad Didáctica}

Resumen: Este artículo tiene como objetivo presentar un sistema de nociones teóricas utilizadas para describir, evaluar y comparar cómo dos profesoras de la enseñanza básica pública y privada de la ciudad de Vitória da Conquista - Bahía, Brasil, dirigieron su atención a las emociones en sus prácticas matemáticas, cuando trabajaban en el mismo contenido matemático: Productos notables. Dentro de un abordaje cualitativo, la observación participante fue utilizada como técnica principal de recopilación de datos, con la ayuda de los instrumentos diario de campo y grabadora de audio. Al establecer un análisis general y comparativo entre las prácticas observadas, a la luz del referencial teórico de los Criterios de Idoneidad Didáctica (CID), encontramos que la docente que ha 
dado mejor atención a los Criterios Afectivos, a partir de la realización de actividades motivadoras, tuvo, en consecuencia, la elevación de los demás Criterios de Idoneidad en su práctica matemática.

Palabras clave: Emociones. Práctica Matemática. Criterios de Idoneidad Didáctica. Productos notables.

\section{Introdução}

Nas últimas décadas, as mudanças promovidas pelas tecnologias e pelas ciências avançadas, cada vez mais, vêm impulsionando as pessoas a modificarem sua forma de relacionar-se, tanto com a vida, quanto consigo mesmas. Dirigindo a atenção ao contexto educacional, vemos professores e alunos vivendo uma fase marcada por dificuldades, incertezas e ausência de valores humanos. Uma desenfreada onda de violência assola ambientes familiares e educativos. Em momentos anteriores à pandemia, vários foram os noticiários de docentes sendo agredidos fisicamente pelos estudantes. Esse contexto leva-nos a refletir sobre as emoções, especialmente as de jovens estudantes que diariamente são tensionados pela complexidade do mundo em que vivem e também do contexto escolar, como é o caso da aprendizagem matemática (REGO e ROCHA, 2016) e, a refletir principalmente sobre como o professor percebe essas emoções e que atenção dá a elas em sala de aula.

Sob esse aspecto e com a finalidade de descrever a complexidade dos fatores emocionais que poderão emergir na sala de aula de Matemática, apontamos como objeto deste estudo as emoções na prática matemática de professores. Por prática matemática, entendemos, em conformidade com Godino, Batanero e Font (2007), toda ação ou expressão (verbal, gráfica) realizada para resolver problemas matemáticos e comunicar a outros a solução obtida.

Essa pesquisa foi desenvolvida no Programa de Pós-Graduação em Educação Científica e Formação de Professores da Universidade Estadual do Sudoeste da Bahia e teve como aparato teórico e metodológico o Enfoque Ontossemiótico do Conhecimento e Instrução Matemática1 (EOS) de Godino e colaboradores, que adota como ponto de partida a organização de uma ontologia dos objetos matemáticos, considerando três aspectos da Matemática: como atividade de resolução de problemas socialmente compartilhada, como linguagem simbólica e como sistema conceitual logicamente organizado (GODINO; BATANERO e FONT, 2007). O EOS nos apresenta um conjunto de ferramentas teóricas, dentre as quais nos foi especialmente útil os Critérios de Idoneidade Didática (CID), que servem para guiar tanto os processos de ensino e aprendizagem da Matemática como para avaliar a sua implementação. (AMORIM, FONT e GUSMÃO, 2017, 2021; GODINO, 2011, 2013; GODINO, CONTRERAS e FONT, 2006; GODINO et al., 2009, 2013; MOREIRA, GUSMÃO e FONT, 2018; dentre

1 De acordo com Godino et. al (2009) "Instrução Matemática" - ou processo de estudo matemático - é o processo de ensino e aprendizagem de conteúdos matemáticos específicos, organizado no âmbito dos sistemas didáticos. 
outros). $O$ componente emoções é contemplado em um dos Critérios da Idoneidade Didática, detalhado mais adiante.

O objetivo principal deste estudo foi analisar a atenção dada à dimensão emocional em práticas matemáticas, realizadas por duas professoras do Ensino Fundamental II, quando trabalharam os mesmos conteúdos matemáticos: os Produtos Notáveis. A escolha por este conteúdo deveu-se, fundamentalmente, por dois fatores: ambas as docentes lecionavam no $8^{\circ}$ ano e pelo fato de tal conteúdo ser, de acordo com as mesmas, o que os alunos apresentavam menor motivação e maiores dificuldades de aprendizado. Os Produtos Notáveis são expressões algébricas ou polinômios que aparecem com mais frequência em cálculos algébricos, sendo um dos conteúdos de muita relevância, pois facilita os cálculos, reduzindo o tempo de resolução e, são utilizados principalmente para a fatoração de polinômios, como também para evitar erros com sinais. (MELO, 2014).

A pesquisa, de cunho qualitativo, adotou a Observação Participante como principal técnica de produção dos dados. Como instrumentos, utilizamos de forma complementar o questionário, o diário de campo e o gravador de áudio, no sentido de nos apropriarmos das diversas possibilidades de manifestações do objeto em estudo.

No decorrer da pesquisa, percebemos que a falta de habilidade de professores em trabalhar com os aspectos emocionais, emergentes do processo de ensino e aprendizagem, pode desestimular a participação e o aprendizado de seus estudantes. Essa situação, de acordo com Gusmão, Silva e Dória (2019), na maioria dos casos, é reflexo da crença pautada na concepção de emoção como potência desorganizadora, como impróprias ou desagradáveis. Professores e alunos parecem ter consciência dos motivos que geram as emoções, todavia desconhecem os processos emocionais que as desencadeiam.

\section{As Emoções e seu enfoque no ensino de Matemática}

No âmbito geral da Educação, adotamos em nossa pesquisa a concepção walloniana de afetividade, emoção e sentimentos. Wallon (1995) defendia a gênese da pessoa, isto é, o estudo da pessoa completa integrada ao meio em que está imersa, com seus aspectos afetivos, cognitivos e motores, também integrados. Dessa forma, a afetividade foi por nós concebida como a capacidade que o ser humano tem de afetar e ser afetado pelo mundo interno e externo e está associada a um grande sistema que abarca os sentimentos, as emoções e as paixões (AMORIM, 2017).

Para Wallon (1995), a emoção é a exteriorização da afetividade, uma expressão ou atitude diante uma situação ou comportamento social na sua função de adaptar-se ao meio em que vive. Ela está associada a um evento fisiológico nos seus componentes humorais e motores, reações ocasionais, 
instantâneas e diretas que decorem da função postural que correspondem a variações viscerais e musculares. Já os sentimentos não envolvem uma reação direta e rápida como a emoção: são reações menos instintivas e mais refletidas. A pessoa tem consciência de que está sentindo e sabe o porquê, entretanto não é algo incontrolável e com sinais biológicos, ou seja, é inteiramente psicológico e consciente.

Ainda de acordo com Wallon (1995), existem dois fatores essenciais para a construção da personalidade humana. Primeiramente, entra em cena a afetividade para, em seguida, surgir no novo ser a inteligência. Nesta perspectiva, no decorrer da vida desse novo ser, a afetividade e a cognição passam por um longo processo de construção. Ambas evoluem e alternam-se na sua preponderância ao longo do desenvolvimento biossocial do indivíduo: existem momentos em que a criança está mais voltada para o conhecimento de si - direção centrípeta cujo predomínio é a afetividade; e outras, em que o indivíduo está mais voltado para o conhecimento do mundo exterior - direção centrífuga cujo predomínio é o conhecimento. Pode-se dizer, portanto, que a constituição da pessoa se dá por momentos afetivos e cognitivos, não de forma separada, mas, sim, articulada.

O ideal para Wallon (1995) seria estabelecer o equilíbrio entre a cognição e as reações emocionais. Todavia, mesmo sendo intensa a relação entre emoção e inteligência, nem sempre este equilibrio será possivel por causa da supervalorização intelectual do meio ou devido à intensa subordinação emocional em algumas pessoas. Para ele, os sucessos do campo das emoções são também percebidos pelo âmbito da racionalidade, e vice - versa.

No âmbito da Educação Matemática, em estudos realizados por Amorim e Gusmão (2010); Amorim (2017); Gusmão, Dória e Silva (2019), ainda é perceptível a supervalorização intelectual dos alunos em detrimento às emoções por parte dos professores, principalmente nas aulas de Matemática, e isso vem gerando consequências desastrosas no âmbito educacional da atual sociedade, uma vez que as emoções, na maioria das vezes, são concebidas como algo danoso que pode influenciar negativamente o raciocínio.

Essa herança questionável da valorização da razão em detrimento à emoção, principalmente na área de exatas, tende a reproduzir nos indivíduos uma busca incessante de controlar as emoções ou tentar separar os sentimentos da razão. Há um desconhecimento de como funcionam os processos emocionais, qual sua natureza, como se manifestam, e que tem levado professores e alunos a apresentarem dificuldades em lidar com as emoções na sala de aula. (AMORIM, 2017; AMORIM e GUSMÃO, 2010; GUSMÃO, DÓRIA e SILVA, 2019). 
Somado a isso, na sociedade atual, com o enfraquecimento do papel da família, a crise de valores e o predomínio das relações impessoais e anônimas, está cada vez mais difícil o papel do professor. É exigido desse profissional a necessidade de uma atuação maior na dimensão afetiva. Mas como podem os professores ensinar a desenvolver em seus alunos a competência emocional, se a maioria deles não teve formação para tal atribuição?

Uma breve análise dos fluxogramas e matrizes curriculares de cursos de licenciaturas em Matemática das universidades públicas da Bahia² evidenciam a inexistência de disciplinas obrigatórias que dão ênfase aos aspectos emocionais presentes no processo de ensino e aprendizagem no campo específico da Matemática. Das matrizes curriculares analisadas, apenas o curso "Matemática com Enfoque em Informática", do Campus de Jequié, chega mais próximo do desejado ao ofertar como disciplina optativa "Contribuições da Psicologia Educacional à Educação Matemática" que atrela as emoções à especificidade do conteúdo matemático.

O que podemos evidenciar no caso particular da Bahia e quiçá do Brasil é que, no geral, há uma grande lacuna curricular quando nos referimos à competência emocional nos cursos de formação docentes, principalmente nas licenciaturas em Matemática.

\section{Os Critérios de Idoneidade Didática do Enfoque Ontossemiótico}

O Enfoque Ontossemiótico do Conhecimento e Instrução Matemática (EOS) de Godino e colaboradores pode ser resumido como um marco teórico que integra diferentes abordagens da Educação Matemática, a partir de pressupostos antropológicos e semióticos e adotando princípios didáticos do tipo socioconstrutivista e interacionista para estudar os processos de ensino e aprendizagem da Matemática. (GODINO, 2011, 2013, 2021; GODINO, CONTRERAS e FONT, 2006; GODINO et al., 2009, 2013).

Nesta perspectiva, o EOS surge como aparato teórico e metodológico que proporciona tanto a análise dos sistemas de práticas manifestados por um sujeito frente à resolução de situações problemas, como também a construção de um modelo integrador de várias teorias ${ }^{3}$ da Educação Matemática (EM) e atribui um papel central à linguagem, aos processos de comunicação e interpretação, permitindo descrever como o objeto matemático surge na sala de aula (GODINO, 2011, 2021).

\footnotetext{
${ }^{2}$ Algumas dessas matrizes e fluxogramas estão expostas nos sites: www.uesb.br, www.ufba.br, www.uesc.br, www.uneb.br

3 São exemplos das teorias que integram o EOS: Teoria das Situações Didáticas (BROUSSEAU, 1986-1997), Teoria dos Campos Conceituais (VERGNAUD, 1990) e Teoria Antropológica (CHEVALLARD, 1992-1999).
} 
Dentre as ferramentas teórico metodológicas do EOS se encontra os Critérios de Idoneidade Didática. $O$ termo idoneidade refere-se, aqui no Brasil, à adequação, portanto, pode ser entendido como Critério de Adequação Didática. Optamos por adotar a mesma nomenclatura dos autores.

Godino, Batanero e Font (2007) consideram que a idoneidade didática de uma prática matemática se define com a articulação coerente e sistêmica dos seis componentes seguintes:

- Idoneidade epistêmica: representatividade do significado institucional implementado (ou pretendido) como diz respeito ao significado de referência previamente definido.

- Idoneidade cognitiva: até que ponto o significado institucional implementado (ou pretendido) é incluídos na 'zona de desenvolvimento proximal' dos alunos (Vygotski, 1934), e a proximidade de significados pessoais alcançados para serem implementados (ou significado pretendido).

- Idoneidade interacional: até que ponto a didática configurações e trajetórias permitem identificar e resolver conflitos semióticos que podem acontecer durante 0 processo instrucional.

- Idoneidade de mediacional: disponibilidade e adequação dos recursos materiais e temporais necessários para desenvolver o processo de ensino e aprendizagem.

- Idoneidade emocional: o envolvimento dos alunos (interesse, motivação, ...) no processo de estudo.

- Idoneidade ecológica: até que ponto o ensino e o processo de aprendizagem se encaixa no projeto educacional, o escola e sociedade, e levar em consideração o fatores condicionantes do ambiente em que é desenvolvido. (GODINO, BATANERO e FONT, 2007, p.133, tradução nossa)

Tais critérios são representados pelo esquema a seguir:

Figura 1: Critérios de Idoneidade Didática (CID)

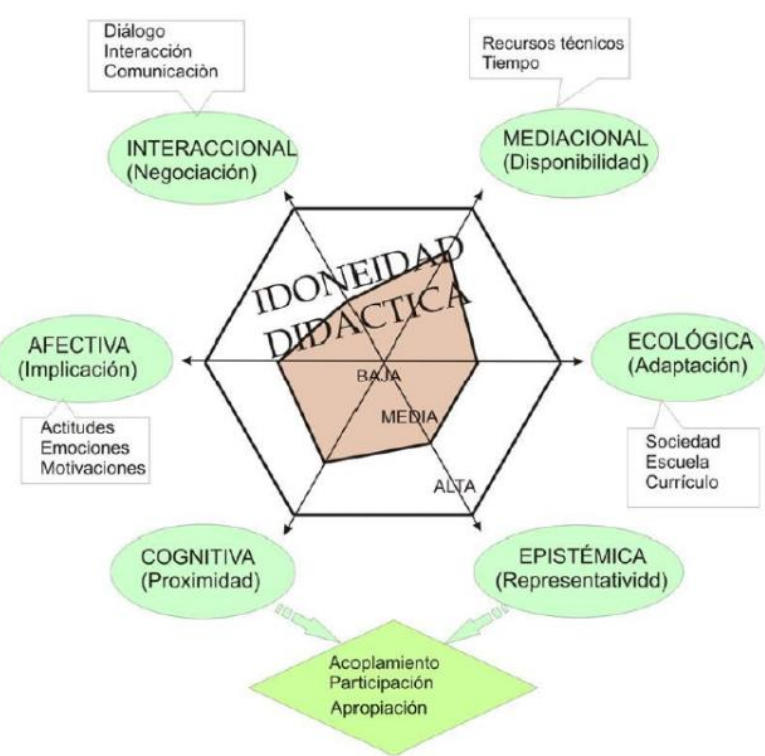

Fonte: Godino (2011) 
De acordo com Breda, Font e Lima (2015), a Idoneidade Didática pode ocorrer em níveis baixo, médio ou alto e o hexágono regular externo, mostrado acima, corresponde à adequação de um processo ou estudo pretendido, no qual se supõe um grau máximo das idoneidades parciais. Já o hexágono irregular interno corresponde ao que foi, de fato, alcançado na realização de um processo/estudo. Por considerarem que o processo de ensino e aprendizagem gira em torno dos conhecimentos específicos, os autores situaram as dimensões epistêmica e cognitiva na base do hexágono.

Dentro dessa perspectiva, podemos notar que a análise didática de uma prática deve abranger o currículo, o conteúdo matemático, o professor, os alunos, o contexto institucional e social, os meios e os recursos utilizados e que todos estes aspectos são relevantes dentro da construção e avaliação dessa prática e, portanto precisam ser levados em consideração. Temos ainda com Godino, Batanero e Font (2007) que a adequação de uma dimensão apenas não garante a adequação global do processo de ensino e aprendizagem e que todos os critérios devem estar integrados considerando as interações entre os mesmos. Assim, o alto grau de adequação de uma das dimensões - cognitiva, interacional etc, isoladamente, não garantirá a qualidade de um método ou de uma tarefa como um todo. É preciso que haja um equilíbrio entre as dimensões (AMORIM, 2017).

\section{Materiais e Métodos}

Optamos pela abordagem de pesquisa qualitativa, uma vez que esta é capaz de fornecer dados descritivos por meio do contato direto do pesquisador com a situação estudada, dando mais ênfase ao processo que o produto em si, além de valorizar a perspectiva dos participantes (BOGDAN e BIKLEN, 1994). Dentro dessa abordagem, utilizamos a Observação Participante como a principal técnica de produção de dados. Entendemos que ela possibilita o contato direto do pesquisador com o fenômeno observado, para recolher as ações dos atores em seu contexto natural, a partir de sua perspectiva e seu ponto de vista (CHIZZOTTI, 2008). As observações foram realizadas nas aulas de Matemática de duas professoras do Ensino Fundamental II, uma da rede pública e a outra privada do município de Vitória da Conquista, Bahia, Brasil, que gentilmente participaram da pesquisa. As observações abrangeram um componente descritivo que abarcou uma anotação minuciosa do que aconteceu "no campo" e, um componente reflexivo dos registros incluiu as observações pessoais do pesquisador (como os sentimentos, impressões, pré-concepções), no momento da análise dos dados. Vale ressaltar que explicitamos os objetivos da pesquisa às docentes e que seriam observadas segundo os Critérios de Idoneidade Didática do EOS, mas não sinalizamos quais seriam estes critérios, no intuito de evitar a mudança de comportamentos dessas profissionais. 
Como instrumentos, utilizamos um gravador de áudio, um questionário para delineamento do perfil das duas professoras participantes e um diário de campo. Tais instrumentos de obtenção de dados, conforme defendem Lüdke e André (1986, p. 28) "utilizamos de forma complementar, no sentido de nos apropriarmos das diversas possibilidades de manifestações do objeto em estudo".

As observações foram iniciadas após a aprovação do projeto no Comitê de Ética. Como pretendíamos analisar o tratamento direcionado à dimensão emocional nas práticas matemáticas e, ao mesmo tempo, comparar essas práticas, optamos por observar as aulas de um mesmo conteúdo para facilitar análise e avaliação dos dados. A escolha por Produtos Notáveis deveu-se, fundamentalmente, por dois fatores: ambas as professoras lecionavam no $8^{\circ}$ ano e pelo fato de tal conteúdo ser, de acordo com as professoras, o que os alunos apresentavam menor motivação e maiores dificuldades de aprendizado.

Após as observações, aplicamos um questionário às professoras, com o intuito de delinearmos o perfil das docentes. Nele construímos 16 questões (10 abertas e 6 fechadas), com 0 intuito de identificarmos suas jornadas de trabalho, o tempo de magistério, seus processos de ensino e aprendizagem da Matemática, os planejamentos das aulas, convicções, valores, prioridades e inquietações acerca da profissão, e, principalmente, suas opiniões e percepções com relação aos aspectos emocionais presentes em sala de aula, entre outros questionamentos.

\section{$5 \quad$ Análise de Resultados}

Os Critérios de Idoneidade foram tomados neste trabalho como marco teórico e metodológico. Assim, estabelecemos inicialmente seis categorias de análise, sendo elas as seis dimensões dos critérios. 1Idoneidade Epistêmica (Ep.), 2- Idoneidade Cognitiva (Cog.), 3- Idoneidade Mediacional (Med.), 4 Idoneidade Interacional (Int.), 5- Idoneidade Afetivo-emocional (Af.), 6- Idoneidade Ecológica (Ec). No marco do CID, os autores apontam uma série de indicadores para servir de guia para avaliar as idoneidades. Esses indicadores, conforme podem ser apreciados mais adiante, foram em alguns momentos adaptados visando atender aos interesses e necessidades da pesquisa e foram pontuados e avaliados em nível baixo, nível médio e nível alto por uma nota fornecida por um grupo de juízes ${ }^{4}$, formado por três especialistas em Educação Matemática ${ }^{5}$ e conhecedoras dos Critérios de Idoneidade.

\footnotetext{
${ }^{4}$ É importante salientar que a figura de juízes também foi utilizada em estudos no âmbito das estruturas multiplicativas e envolvendo professores. Foi o caso do estudo de Souza (2015), de Santos (2005 apud Souza 2015) e de Costa (2011 apud Souza 2015).

${ }^{5} \mathrm{O}$ grupo de juízes foi formado por uma mestra em Educação Científica e Formação de Professores (UESB), uma mestranda em Ensino, Filosofia e História das Ciências (UFBA) e uma especialista em Metodologia do Ensino de Matemática e Física (UNINTER). Todas graduadas em matemática pela Universidade Estadual do Sudoeste da Bahia.
} 
Este grupo, após ter acesso às gravações de áudio e ao relato das práticas observadas, reuniu-se para estabelecer, consensualmente, uma nota para cada categoria que, por sua vez, viabilizou as representações gráficas dessas práticas por meio das somas das notas obtidas em cada critério. Nessa pontuação, a soma obtida poderá atingir os escores mínimo, médio ou máximo de cada nível (Baixo, Médio ou Alto), conforme mostramos na figura a seguir:

Figura 2: Esboço do hexágono utilizado para a representação gráfica

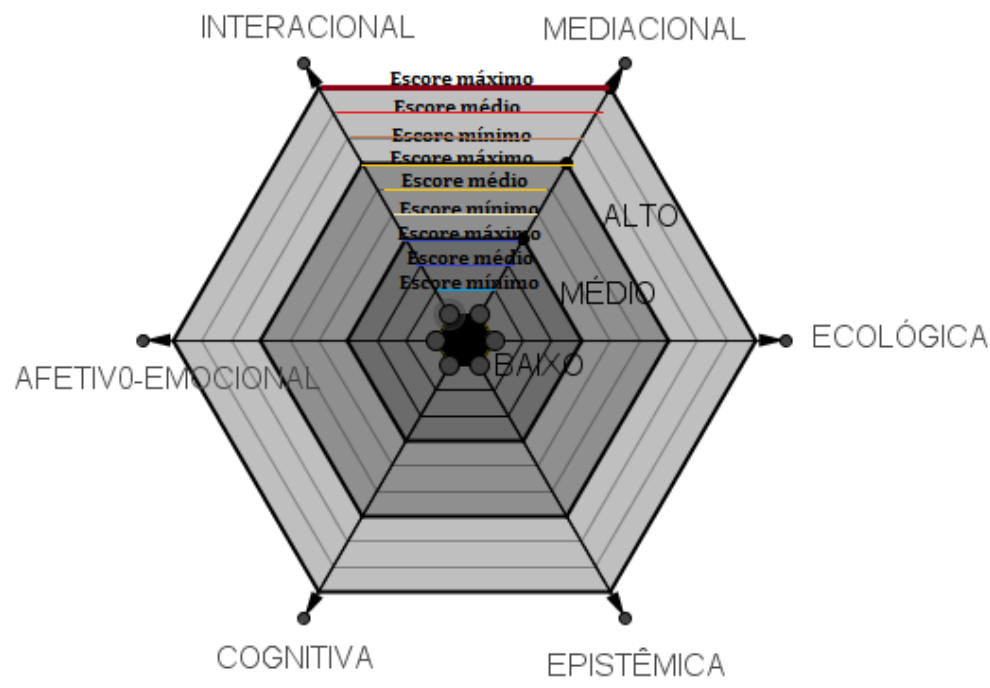

Fonte: Redesenho de AMORIM (2017) a partir de GODINO (2002).

A seguir, apresentamos fragmentos das práticas das professoras durante as observações realizadas, intercalando com pequenas análises de cunho geral para em seguida apresentar um quadro de análises segundo os Critérios de Idoneidade do EOS.

\subsection{Análise da prática da professora Alfredina}

As primeiras duas aulas foram marcadas pela problematização a respeito do termo Produtos Notáveis e pela conceituação desse conteúdo através da exposição participada. As aulas restantes foram direcionadas à correção de exercícios. A professora Alfredina inicia a aula solicitando aos alunos que abrissem o livro didático e questiona-Ihes o significado do termo Produtos Notáveis.

Alfredina: Produtos?

Alunos: Porque está relacionado à multiplicação.

Alfredina: E Notáveis?

Aluna K: Porque é importante? 
Alfredina: Muito importante! São muito utilizados. (DC6, 2016)

Durante a exposição do novo conteúdo, não há contextualização, interdisciplinaridade nem conexão com outros ramos da Matemática, como a Geometria. Nessa perspectiva, de acordo com Gusmão (2010), podemos inferir que professores e futuros professores, embora apresentem capacidades de resolução numérica, domínio de técnicas de cálculo, revelam dificuldades quando se trata de justificar as suas ações, os seus cálculos, e, portanto, revelam suas fragilidades no domínio do conteúdo matemático e didático.

Todavia, a professora, ao solucionar a expressão algébrica proposta com uma linguagem clara, obtém a participação intensa dos alunos por explorar seus conhecimentos prévios: o método da distributividade, já trabalhado no assunto anterior.

Em seguida, a professora expõe um novo exemplo: $\left(\frac{\mathbf{a}^{2}}{2}+\sqrt{2}\right)^{2}$ e apresenta a resolução pela regra dos Produtos Notáveis. 0 termo chuveirinho ${ }^{7}$ é amplamente utilizado em substituição da propriedade distributiva, uma vez que os alunos demonstram a predileção por este termo.

Alfredina: Então fica: $\left(\frac{a^{2}}{2}\right)^{2}+2 \cdot \frac{a^{2}}{2} \cdot \sqrt{2}+(\sqrt{2})^{2}$. Não precisa multiplicar pelo chuveirinho. Vocês concordam comigo que é mais fácil resolver por este método?

Alunos (maioria): Ham ham! [Expressão afirmativa]

Alunos D: E por que multiplica por esse dois, professora?

Alfredina: Porque o dois é da estrutura da resolução dos produtos notáveis. Agora é só resolver isso aqui. Como é que eu resolvo a potência de uma fração? O numerador elevado a essa potência e o numerador elevado a essa potência [e resolve explicando: $\frac{\left(\mathrm{a}^{2}\right)^{2}}{2^{2}}=\frac{\mathrm{a}^{4}}{4}$ ].

Aluna B: Não, péra, calma aí! [a expressão no rosto da aluna é de aflição] Por que deu $a^{4}$ ? $\left(G A / D C^{8}, 2016\right)$

Podemos perceber, inicialmente, um conflito cognitivo apresentado pelo aluno $D$ quando 0 mesmo não consegue perceber ou fazer a analogia de parte da expressão apresentada, anteriormente, pelo professor: $\left(\frac{a^{2}}{2}+\sqrt{2}\right) \times\left(\frac{a^{2}}{2}+\sqrt{2}\right)$ com a nova: $\left(\frac{a^{2}}{2}+\sqrt{2}\right)^{2}$. A professora parece dar por óbvia a sua explicação de que "o dois [do expoente] é da estrutura da resolução dos produtos notáveis" e segue

\footnotetext{
6 Trata-se do registro escrito das observações, construído durante a observação, que nomearemos por Diário de Campo (DC).

7 O termo chuveirinho é utilizado na distribuição de valores, uma vez que as setas facilitadoras faz lembrar a forma de

8 Trata-se de registros escritos do Diário de Campo (DC) e da gravação de áudio (GA), construídos durante a observação.
} 
com a manipulação de técnicas até o final da resolução, quando a aluna B pede-lhe calma, pois necessita compreender parte da expressão do resultado final, "Por que deu $a^{4}$ ?". A pergunta seguida do silêncio (embora em um curto momento) do aluno $D$ e a reação da aluna $B$ indicam estados emocionais, associados à reorganização do sistema cognitivo a partir de um conflito: ao se depararem com um novo conteúdo, ambos os alunos entram em estado de desequilíbrio (no sentido piagetiano) e a necessidade de acomodação do novo estímulo ao esquema preexistente, segundo Mandler ${ }^{9}$ apud Chacón (2003), levará a uma nova ativação fisiológica e a estados avaliativos positivos ou negativos. Eis que surge a emoção.

O novo estado de equilíbrio só aparece quando a aluna B assimila, após a explicação da professora, a resposta aos conteúdos anteriormente estudados:

Alfredina: Porque eu calculei a potência de uma potência. O que você faz? Conserva a base e multiplica os expoentes.

Aluna B: Aaaaah, entendiii! [ao compreeder a resolução, a aluna apresenta uma expressão facial de felicidade e satisfação]. (GA/DC $\left.{ }^{10}, 2016\right)$

É perceptível em sala a resistência que os alunos apresentam ao conteúdo Frações, entretanto, mesmo com a dificuldade apresentada, eles não deixam de participar.

Aluno E: Não professor, é $a^{2} \cdot \sqrt{2}$, você não simplificou!

Alfredina: Eu só simplifico o dois com isso [mostra o número dois do denominador) e acabou. Posso somar $\frac{a^{4}}{4}$ com a $^{2}$ ?Por quê?

Aluna K: Não, porque as partes literais são diferentes.

Aluno D: Se fosse um dois [referindo-se ao expoente de $\left.a^{4}\right]$ dava, né? Ou se fosse um quatro no lugar do dois dava para somar, né? (GA/DC, 2016)

A professora não tece comentário sobre o questionamento do aluno $\mathrm{D}$ e continua:

Alfredina: Como não é possivel somar mais ninguém aqui, o resultado é este [aponta para $\left.\frac{a^{4}}{4}+a^{2} \cdot \sqrt{2}+2\right] \cdot(\mathrm{GA} / \mathrm{DC}, 2016)$

Mesmo os alunos apresentando dificuldades importantes de compreensão de conteúdo matemático como foi o caso dos alunos $\mathrm{D}$ e $\mathrm{E}$, a professora não buscou estratégias diferenciadas $\mathrm{e}$ didáticas visando uma melhor compreensão da matemática apresentada. Fica claro uma metodologia em que ela mesma apresenta e dá resposta para as questões. A professora não percebe e parece não se importar com os estados emocionais gerados pelos conflitos cognitivos. Muitas são as situações

\footnotetext{
9 MANDLER, George. Mind and body. Nova York: Wiley, 1984.

10 Trata-se de registros escritos do Diário de Campo (DC) e da gravação de áudio (GA), construídos durante a observação.
} 
indicadoras de estados emocionais na sala de aula. Entretanto, saber lidar com elas tem sido um grande desafio de professores e alunos (GUSMÃO; DÓRIA e SILVA, 2019).

Alfredina dá prosseguimento à sua aula. Os alunos $\mathrm{P}$ e $\mathrm{S}$ são reprimidos pela professora por conversarem sobre assuntos não relacionados ao conteúdo. Após a reclamação, ambos passaram 0 restante da aula girando o caderno na ponta da caneta e com alto grau de dispersão. Um deles já tinha cochilado os 15 minutos iniciais da aula. Outras três alunas também apresentaram olhares e pensamentos distantes. Alfredina não se importa com a dispersão dos alunos, só se incomoda quando a conversa é retomada.

\begin{abstract}
Alfredina: Então o que que acontece toda vez que você tiver a estrutura disso aqui: a subtração de dois termos elevada ao quadrado, você não precisa desenvolver isso tudo aqui: abrir, distribuir e somar. Você já pode chegar direto no resultado. Nada Ihe impede, se você se esquecer do resultado de fazer a conta aqui. Mas são estruturas que valem a pena decorar porque você utiliza muito.
\end{abstract}

Aluno E: Decorar o quê? Peraê!

Alfredina: Esse resultado aqui. Você sempre vai ter essa estrutura.

Aluno E: Pra que decorar se eu posso fazer a conta?

Aluna B: Aiiii! Não decora não! Deixa quieto, deixa quieto! [a aluna demonstra-se impaciente com o colega]

Aluna K: Porque é mil vezes mais fácil!

Aluno S: É mais fácil tu decorar que ter que fazer a conta. (GA/DC 11,2016$)$

O questionamento do Aluno E "Pra que decorar se eu posso fazer a conta?" não é bem aceito pela professora, muito menos pelos seus colegas que acreditam ser mais fácil a aprendizagem mecânica do conteúdo. Neste sentido, percebemos que a prática da professora não está ancorada em contextos sociais que mostrem claramente as relações existentes entre conhecimento matemático e realidade. Isso acarreta em seus alunos a sensação de que a Matemática é uma matéria difícil e que seu estudo se resume em decorar uma série de fatos matemáticos, sem compreendê-los e sem perceber suas aplicações e que isso lhes será de pouca utilidade.

De todos os assuntos conversados na aula, a avaliação é o que gera mais tensão entre 0 relacionamento alunos/professor. A impressão que se tem é de a avaliação ser utilizada como instrumento de punição e repressão do professor.

\footnotetext{
11 Trata-se de registros escritos do Diário de Campo (DC) e da gravação de áudio (GA), construídos durante a observação.
} 
Aluna K: Oh professor o que vai cair na prova dessa unidade? Vai tá fácil né?

Alfredina: Vai depender do comportamento de vocês.

Aluna C: Oh a gente está quieto, viu?!

Aluna K: Oh professora a gente está participando da aula

Aluna C: A gente está participando

Alfredina: Eu to vendo a conversa aí. [ $E$ sorri]

Aluna C: Cale a boca, povo!

Aluna K: Geeeenteee, faz silênciooo!

Aluna J: Oh véi, silêncio!!!

Aluna B: Poh vei, só faltam quinze dias para prova! (GA/DC, 2016)

Alfredina identifica que a maior dificuldade sentida pelos alunos são os problemas que envolvem frações e nesse momento passa a fazer uma revisão do conteúdo para depois retomar a resolução do Produto Notável.

As aulas que se seguiram foram marcadas pelas correções de exercícios das páginas solicitadas pela professora. As maiores dúvidas dos alunos se concentravam às questões que envolviam o produto notável de números fracionários, e à medida que a professora tecia as explicações os alunos afirmavam compreender o conteúdo.

Aluno S: Moço, eu tô sabendo demais. Eu tô tão orgulhoso de mim!

Aluna K: professora, faz mais um exemplo com fração para a gente resolver! (GA/DC'12, 2016)

Neste momento nota-se a euforia dos alunos provocada pelo ato de aprendizagem. Aprender gera sentimentos de alegrias, conforme Gusmão (2010).

Por fim, a docente propõe a resolução de um desafio: $\left((a+b)^{2}-(a-b)^{2}\right)^{2}$

Aluna K: Pelo amor de Jesus!

Aluna C: Deus me livra! (GA/DC, 2016)

A professora poderia aproveitar a situação de interesse dos alunos, como demonstrado pelo aluno S e K, para estimulá-los no processo de aprendizagem, entretanto a sua postura em persistir na cobrança de questões descontextualizadas inviabiliza a modificação de crenças de seus alunos a respeito da Matemática, contribuindo para o desenvolvimento de atitudes e emoções negativas sobre 0

\footnotetext{
12 Trata-se de registros escritos do Diário de Campo (DC) e da gravação de áudio (GA), construídos durante a observação.
} 
aprendizado desta área de conhecimento e acentuando a baixa autoestima, a rejeição, a fobia e o medo, principalmente do momento avaliativo. (CHACÓN, 2003; GUSMÃO, 2010; GODINO, 2011).

A seguir apresentamos um resumo da análise das seis observações realizadas nas aulas da professora Alfredina, à luz dos Critérios de Idoneidade Didática.

Quadro 1: Resumo da análise da Prática da Professora Alfredina

\begin{tabular}{|c|c|c|c|}
\hline $\begin{array}{l}\text { Critérios de } \\
\text { Idoneidade } \\
\text { Avaliados }\end{array}$ & Indicadores para a análise & $\begin{array}{c}\text { Soma das } \\
\text { notas } \\
\text { dadas } \\
\text { pelos juízes }\end{array}$ & $\begin{array}{c}\text { Nível } \\
\text { contempla } \\
\text { do }\end{array}$ \\
\hline $\begin{array}{l}\text { Idoneidade } \\
\text { Epistêmica } \\
\text { Escore (Níveis): } \\
\text { Mínimo: } 5 \text { a } 35 \\
\text { Médio: } 10 \text { a } 40 \\
\text { Máximo: } 35 \text { a } 45\end{array}$ & $\begin{array}{l}\text { A professora não apresentou formas variadas e articuladas de } \\
\text { situações - problema na exposição do conteúdo Produtos Notáveis } \\
\text { (entretanto contextualiza outro conteúdo, após um questionamento } \\
\text { de um aluno). Quase não houve estabelecimento de relações } \\
\text { significativas entre os objetos matemáticos (definições, propriedades, } \\
\text { proposições etc). Também não procurou explorar o uso dos modos } \\
\text { de expressão gráfica, simbólica e pouco promoveu situações em que } \\
\text { foi explorada a argumentação e o erro dos alunos, ao invés disso, } \\
\text { propôs questões que ela mesma respondeu. Todavia fez uso } \\
\text { adequado da linguagem matemática, apresentou clareza e correção } \\
\text { de definições e procedimentos, dentro do nível escolar. }\end{array}$ & 15 & Baixo \\
\hline $\begin{array}{c}\text { Idoneidade } \\
\text { Cognitiva } \\
\text { Escore (Níveis): } \\
\text { Mínimo: } 5 \text { a } 35 \\
\text { Médio: } 10 \text { a } 40 \\
\text { Máximo: } 35 \text { a } 45\end{array}$ & $\begin{array}{l}\text { Pouco reconheceu e resolveu os conflitos de significado dos alunos. } \\
\text { Explorou o conhecimento prévio dos estudantes e pouco utilizou } \\
\text { recursos argumentativos com a intenção de implicar a participação } \\
\text { do aluno, favorecendo a comunicação entre os estudantes; } \\
\text { contemplou poucos momentos nos quais os estudantes se } \\
\text { responsabilizaram pelo estudo (exploração, formulação, validação). } \\
\text { Não houve adaptações curriculares para as diferenças individuais. As } \\
\text { atividades de ampliação e de reforço pouco levaram em consideração } \\
\text { distintos níveis de compreensão e competência. }\end{array}$ & 15 & Baixo \\
\hline $\begin{array}{c}\text { Idoneidade } \\
\text { Mediacional } \\
\text { Escore (Níveis): } \\
\text { Mínimo: } 4 \text { a } 12 \\
\text { Médio: } 16 \text { a } 24 \\
\text { Máximo: } 28 \text { a } 36\end{array}$ & $\begin{array}{l}\text { Não fez uso de materiais manipulativos concretos e tecnológicos que } \\
\text { permitem introduzir boas situações, linguagens, procedimentos, } \\
\text { argumentações adaptadas ao conteúdo pretendido. A organização da } \\
\text { turma (o número e a distribuição dos alunos) foi adequada e o tempo } \\
\text { foi suficiente para o ensino pretendido, entretanto a professora não } \\
\text { explorou esse tempo para colocar os alunos no centro da } \\
\text { aprendizagem, dando-lhes espaço para resolver por eles mesmos os } \\
\text { problemas e ao invés disso é ela quem tem todo o protagonismo. } \\
\text { Houve uma preocupação da professora em esgotar o conteúdo no } \\
\text { tempo da aula. Suas estratégias se resumiram em apresentar o } \\
\text { conteúdo de forma expositiva e utilizando apenas o quadro e o livro } \\
\text { didático. }\end{array}$ & 14 & $\begin{array}{c}\text { Transição } \\
\text { entre o } \\
\text { BAIXO e o } \\
\text { MÉDIO }\end{array}$ \\
\hline $\begin{array}{c}\text { Idoneidade } \\
\text { Interacional } \\
\text { Escore (Níveis): } \\
\text { Mínimo: } 7 \text { a } 21 \\
\text { Médio: } 28 \text { a } 42 \\
\text { Máximo: } 49 \text { a } 63\end{array}$ & $\begin{array}{l}\text { Propôs uma apresentação adequada do tema, enfatizando os } \\
\text { conceitos chaves (apresentação clara e bem organizada), mas foi } \\
\text { constante a reclamação dos alunos por falar rápido. Pouco } \\
\text { reconheceu e resolveu os conflitos dos alunos. Fez uso de poucos } \\
\text { recursos retóricos e argumentativos para implicar e captar a atenção } \\
\text { dos alunos e facilitar a inclusão dos mesmos na dinâmica da classe. } \\
\text { Não contemplou momentos em que os estudantes assumissem a } \\
\text { responsabilidade do estudo. Explorou exemplos e contraexemplos } \\
\text { para investigar e conjecturar, mas não usou uma variedade de } \\
\text { ferramentas para pensar, estabelecer conexões, resolver problemas } \\
\text { e comunicá-los. }\end{array}$ & 23 & $\begin{array}{c}\text { Transição } \\
\text { entre o } \\
\text { BAIXO e o } \\
\text { MÉDIO }\end{array}$ \\
\hline
\end{tabular}




\begin{tabular}{|c|c|c|c|}
\hline $\begin{array}{c}\text { Idoneidade } \\
\text { Afetivo- } \\
\text { emocional } \\
\text { Mínimo: } 5 \text { a } 35 \\
\text { Médio: } 10 \text { a } 40 \\
\text { Máximo: } 35 \text { a } 45\end{array}$ & $\begin{array}{l}\text { A professora não propôs situações para valorizar a utilidade da } \\
\text { Matemática na vida cotidiana e profissional nem valorizou a qualidade } \\
\text { de estética e precisão dessa área de conhecimento. Por não se dar } \\
\text { conta dos estados emocionais, não foi frequente a promoção da } \\
\text { autoestima para criar gosto pela matemática ensinada. Em ocasiões, } \\
\text { estimulou a participação dos alunos nas atividades, à perseverança } \\
\text { e responsabilidade, entretanto as tarefas nem sempre despertaram o } \\
\text { interesse dos alunos. }\end{array}$ & 14 & BAIXO \\
\hline $\begin{array}{c}\text { Idoneidade } \\
\text { Ecológica } \\
\text { Mínimo: } 5 \text { a } 35 \\
\text { Médio: } 10 \text { a } 40 \\
\text { Máximo: } 35 \text { a } 45\end{array}$ & $\begin{array}{l}\text { Os conteúdos não foram relacionados com outros conteúdos intra e } \\
\text { interdisciplinares. Não foi nítida a contemplação de valores } \\
\text { democráticos e o pensamento crítico. Da forma abordada, os } \\
\text { conteúdos pouco contribuíram na formação socioprofissional dos } \\
\text { estudantes. Não houve integração de novas tecnologias } \\
\text { (calculadoras, computadores, TIC etc.), no projeto educativo. } \\
\text { Entretanto, os conteúdos, sua implementação e a avaliação } \\
\text { corresponderam com as diretrizes curriculares. }\end{array}$ & 12 & BAIXA \\
\hline
\end{tabular}

Fonte: Amorim (2017) a partir dos Critérios de Idoneidade Didática

\subsection{Análise da prática da Professora Betânia}

A professora Betânia inicia a abordagem do conteúdo Produtos Notáveis alertando seus alunos que a falta de domínio desse conteúdo compromete tanto a aprendizagem do próximo assunto (Fatoração) como todos os outros que estudarão no $9^{\circ}$ ano e demais séries da Educação Básica. Em seguida, ela dá prosseguimento à conceituação do assunto:

Professora Betânia: Vamos começar o conteúdo falando justamente da expressão "Produtos Notáveis". Vamos ver o significado: primeiro o que é produto? Mul-ti-pli-cação. O resultado de uma multiplicação... é uma multiplicação. Notável... O que é notável?

Aluno $\alpha$ : É que se destaca...

Professora Betânia: É uma coisa que se destaca... é uma coisa que se diferencia das outras. Então os produtos notáveis, no contexto aqui, né? De polinômios, são aqueles produtos que mais vezes acontece, viu?! [...] A partir de agora... Lá no $9^{\circ}$ ano, no $1^{\circ}$ ano, no $2^{\circ}$ e no $3^{\circ}$ vocês vão ver inúmeras vezes, tanto produtos notáveis quanto fatoração. [...](GA/DC $\left.{ }^{13}, 2016\right)$

Para introduzir o novo assunto, a professora além de explorar os conhecimentos prévios dos estudantes, argumenta também a importância e sentido de se aprender tal conteúdo.

Professora Betânia: Vamos lá aos três Produtos Notáveis. O primeiro é o que mais aparece que é oh: o quadrado da soma de dois termos [e copia no quadro]. Uma situação aqui oh: ( $x$ $+y)^{2}$. O que que é isso daqui gente? O quadrado de uma soma. De quantos termos?

Alunos (maioria): Dois.

Professora Betânia: Dois termos, tá bom? Oh... assim como na [multiplicação], lembra do que eu falei aqui, a gente pode resolver aqui somando $8+8+\ldots$, não é? Pode resolver assim. Os Produtos Notáveis a gente pode resolver também usando outras técnicas senão... que não seja as regras lá de produto notável, oh: $(x+y)^{2}$ é a mesma coisa de o que gente?

Alunos (maioria): $(x+y) \cdot(x+y)$

\footnotetext{
${ }^{13}$ Trata-se de registros escritos do Diário de Campo (DC) e da gravação de áudio (GA), construídos durante a observação.
} 
Professora Betânia: Isso... $(x+y)^{2}$ é... ele vezes ele mesmo, certo? Pronto! Vamos resolver essa situação aqui utilizando...

Alguns alunos: 0 chuveirinho.

Professora Betânia: O chuveirinho que é a distributiva. Tá certo?Vai dá quanto? [e aponta para $(x+y) \cdot(x+y)]$.

Alunos (maioria): $x^{2}+x y+y x+y^{2}$

Professora Betânia: Somando aí, o que a gente obtém? $x^{2}+\ldots$

Alunos (maioria): $+2 x y$

Professora Betânia: Muito bem!

Alunos (maioria): $+y^{2}$

Aluna є: Oh, por que 2xy? [expressão de insatisfação]

Aluno $\alpha$ : Não poderia ser elevado não né? [Referindo-se ao 2xy]

Aluna Y: Isso que eu ia falar...

Professora Betânia: Não, é soma... e o que a gente faz na soma? Soma os coeficientes e conserva...

Alunos (maioria): a base!

Professora Betânia: A parte literal. Conserva a parte literal, certo?

Aluno $\alpha$ : Entendi!

Aluna є: Aaaah!!! [ a aluna retoma com a expressão de satisfação] (GA/DC $\left.{ }^{14}, 2016\right)$

É perceptível que, ao longo da exposição conceitual, a professora evita o desenvolvimento do obstáculo emocional em sala de aula: os alunos não apresentam temor pelo erro. Neste sentido, o erro não é visto nessa prática como algo a ser evitado e/ou punido, mas sim como uma das etapas para o processo de construção do conhecimento, uma vez que, segundo a perspectiva construtivista, a evolução da inteligência e do conhecimento provém de situações perturbadoras, conforme defendem Gusmão e Emerique (2000).

A conexão intradisciplinar também é contemplada no momento que esta profissional utiliza a Geometria como suporte para explicar e dá sentido aos conceitos algébricos:

Professora Betânia: Nós resolvemos essa multiplicação aqui oh: [e aponta para $(x+y)$. (x $+\mathrm{y})$ ] algebricamente, a gente utilizou a propriedade distributiva. Os gregos... eles não usavam... a gente, pelo menos esse aqui, a gente vai responder essa multiplicação aqui [...] também na maneira geométrica, da maneira gráfica... nós vamos encontrar essa multiplicação aqui não utilizando a distributiva, mas utilizando o quê? Gráficos... que vocês terão, inclusive, atividades assim...com gráficos. Olha só... [e desenha no quadro a ] (GA/DC, 2016)

\footnotetext{
14 Trata-se de registros escritos do Diário de Campo (DC) e da gravação de áudio (GA), construídos durante a observação.
} 
Figura 3: Representação geométrica feita no quadro pela professora Betânia

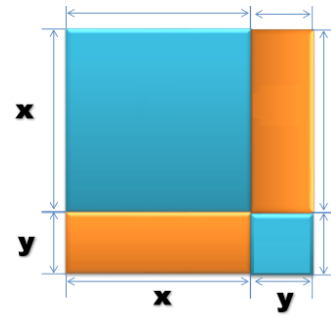

Fonte: Criação com base no esquema feito pela professora

Professora Betânia: Isso é um quadrado: nesse intervalo mede $x$, nesse intervalo mede $y$, esse intervalo mede y e esse aqui mede $x, o k$ ? [referindo às medidas lados do quadrado desenhado. É... é um quadrado, né? Então os lados os quadrados são iguais, é claro! Então quanto mede esse lado aqui, gente?

Alunos (maioria): $x y$

Professora Betânia: $x y$ ?

Aluna $\epsilon$ : Isso!

Professora Betânia: Quanto é que mede aqui? \{referindo-se ao lado da base]

Alunos (maioria): $x+y$

Professora Betânia: olha só... se a gente quer encontrar a área desse quadrado aqui a gente [e aponta para o todo] vai multiplicar...

Alunos (maioria): $(x+y)$ vezes $(x+y)$

Professora Betânia: só que isso nós fizemos aqui algebricamente, nós vamos descobrir 0 quadrado da soma de dois termos geometricamente. E aí o que a gente vai fazer? Descobrir a área de cada uma dessas regiões para depois somá-las, não é, Seu Thiago15?", [e aponta para os dois quadrados e os dois retângulos que o quadrado maior abrange].

Aluna $\epsilon$ : Êh Tiagão... (GA/DC16, 2016)

Embora a professora parece não ter a intenção de antecipar as respostas, em ocasiões ela acaba o fazendo. Entretanto, fica claro em todas as suas ações empreendidas o desejo que ela tem de 0 aluno participar do diálogo. A todo o momento os alunos são questionados e, na maioria das vezes, suas perguntas são respondidas com outra pergunta, buscando estimular o raciocínio lógico e a autonomia dos discentes, além de evitar o que Brousseau (1986) denominou de Efeito Topázio17.

\footnotetext{
15 Nome fictício dado ao aluno.

${ }^{16}$ Trata-se de registros escritos do Diário de Campo (DC) e da gravação de áudio (GA), construídos durante a observação. 17 Durante a prática pedagógica da matemática podemos observar certas situações em que o aluno sente-se bloqueado diante da dificuldade momentânea de resolver um problema. Diante dessa dificuldade do aluno, o professor pode ser levado a tentar acelerar a aprendizagem, antecipando o resultado que deveria ser alcançado pelo esforço do próprio aluno. Brousseau denominou essa situação como efeito Topázio.
} 


\section{revemop}

Além disso, é mínimo o grau de dispersão dos alunos no momento da exposição participada do conteúdo. E mesmo quando isso ocorre, a professora tem o cuidado de chamar a atenção para si: "Não

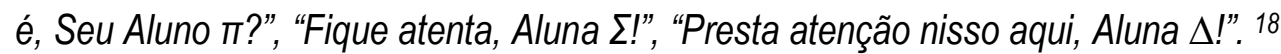

Entretanto, a turma se apavora quando a professora propõe um exemplo envolvendo números fracionários:

Aluno $\Delta$ : Vê outro exemplo que tenha fração, professora?

Professora Betânia: Vamos ver outro exemplo agora de fração, né Aluno $\Delta:$ ? também... [e escreve no quadro o exemplo $\left(\frac{3}{2}+\frac{x}{3}\right)^{2}$ ]

Alunos (maioria): Êeeeê! [reprovação da turma]

Aluno $\theta$ : Eeeê! Aluno $\Delta$, fica dando ideia!

Aluna $\Sigma:$ Ah não, Fração?!

Aluno $\Omega$ : Eu não gosto de fração!

Alunos $\epsilon$ : Ave Maria!

Aluno $\Delta$ : Não bota isso na prova não, professor!

Alunos $\alpha$ : Tem que aprender, Aluna $\Sigma$ !

Professora Betânia: Oh gente, o Aluno $\Delta$ deu a ideia de coisas que eu vou cobrar, se Aluno $\Delta$ não tivesse dado a ideia, inclusive nas atividades tem... vocês iam encontrar dificuldade na atividade!

Aluna $\Sigma$ : É verdade! (GA/DC, 2016)

Com essa ação, a professora solucionou um conflito de interação entre aluno/aluno, reforçando que a solicitação do Aluno $\alpha$ era algo que beneficiava a todos. E a aula continuou com a mesma participação, mesmo com o nível de complexidade de o exemplo ter aumentado.

Depois de um número considerável de questões solucionadas, Betânia escuta a reclamação da aluna $\Sigma$ :

\section{Aluna $\Sigma$ : Ah, isso tá chato!}

A professora Betânia percebe o descontentamento e o desprezo da Aluna Z e diante da crítica, ela interrompe a correção, pergunta se alguma dúvida ainda persistia e anuncia a aplicação de uma atividade envolvendo a manipulação de figuras geométricas "Jogando com a Álgebra". As expressões de felicidade e empolgação dos alunos são manifestadas em suas faces.

A partir do momento em que a professora abandona a atividade enfadonha e empreende outra atividade de caráter lúdico, ela obteve êxito no que Codo; Menezes (1999) denominou de "jogo de sedução", conquistando a atenção e despertando o interesse do aluno para o conhecimento que ela

\footnotetext{
18 Nomes fictícios dados aos alunos.
} 
estava querendo abordar. Formou-se uma corrente de afetividade, propiciando uma troca entre professora/alunos e alunos/alunos. (CODO; MENEZES, 1999, p.50)

Os alunos não obtiveram dificuldades na resolução da atividade empreendida, conforme é mostrado nas fotos a seguir:

Figura 4: Resolução dos três casos de produtos notáveis pelos estudantes

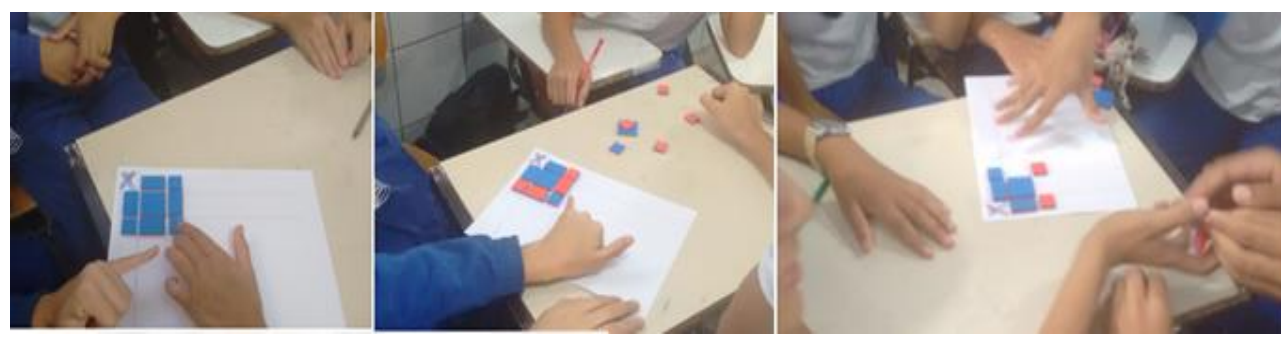

Fonte: Arquivo da primeira autora.

Após o desenvolvimento da representação geométrica, os estudantes se empenharam na formalização da representação simbólica. Nesse momento, a professora sugeriu que houvesse interação entre os grupos para chegar a uma resposta em comum. No final, a professora verificou e percebeu que as respostas obtidas por alunos estavam corretas.

Quadro 2: Resumo da análise da Prática da Professora Betânia

\begin{tabular}{|c|c|c|c|}
\hline $\begin{array}{c}\text { Componentes de } \\
\text { Avaliação }\end{array}$ & Indicadores para a análise & $\begin{array}{c}\text { Soma das } \\
\text { notas } \\
\text { dadas } \\
\text { pelos juízes }\end{array}$ & $\begin{array}{c}\text { Nível } \\
\text { contempla } \\
\text { do }\end{array}$ \\
\hline $\begin{array}{l}\text { Idoneidade } \\
\text { Epistêmica } \\
\text { Escore (Níveis): } \\
\text { Mínimo : } 5 \text { a } 35 \\
\text { Médio: } 10 \text { a } 40 \\
\text { Máximo: } 35 \text { a } 45\end{array}$ & $\begin{array}{l}\text { A apresentação de formas variadas e articuladas de situações - } \\
\text { problema foram pouco exploradas pela professora. Esta, na maioria } \\
\text { das vezes, procurou explorar o uso dos modos de expressão verbal, } \\
\text { gráfica, simbólica etc. Houve adequação da linguagem matemática, } \\
\text { clareza e correção de definições e procedimentos dentro do nível } \\
\text { escolar a que se está voltado. Promoveu situações em que foi } \\
\text { explorada a argumentação e o erro dos alunos, entretanto houve } \\
\text { pouco estabelecimento de relações significativas entre definições, } \\
\text { propriedades, problemas do tema estudado. }\end{array}$ & 30 & Médio \\
\hline $\begin{array}{l}\text { Idoneidade } \\
\text { Cognitiva } \\
\text { Escore (Níveis): } \\
\text { Mínimo: } 5 \text { a } 35 \\
\text { Médio: } 10 \text { a } 40 \\
\text { Máximo: } 35 \text { a } 45\end{array}$ & $\begin{array}{l}\text { Utilizou recursos argumentativos para melhorar a aprendizagem; } \\
\text { procurando facilitar sua inclusão na dinâmica da aula; favorecendo a } \\
\text { comunicação entre os estudantes; contemplando momentos nos } \\
\text { quais os estudantes se responsabilizaram pelo estudo (exploração, } \\
\text { formulação, validação). As atividades de ampliação e de reforço, } \\
\text { realizadas em sala, levaram em consideração distintos níveis de } \\
\text { compreensão e competência. }\end{array}$ & 33 & $\begin{array}{c}\text { Transição } \\
\text { entre o } \\
\text { MÉDIO e o } \\
\text { ALTO }\end{array}$ \\
\hline $\begin{array}{l}\text { Idoneidade } \\
\text { Mediacional } \\
\text { Escore (Níveis): } \\
\text { Mínimo: } 4 \text { a } 12 \\
\text { Médio: } 16 \text { a } 24\end{array}$ & $\begin{array}{l}\text { A estratégia da professora não se resumiu em apresentar o conteúdo } \\
\text { de forma expositiva, pois utilizou outros recursos, além do quadro e o } \\
\text { livro didático e adotou diferentes estratégias e metodologias para } \\
\text { comunicar os conteúdos planejados e argumentar sobre eles. } 0 \\
\text { tempo não foi suficiente para o ensino pretendido, entretanto buscou } \\
\text { colocar os alunos no centro da aprendizagem, dando-lhes espaço } \\
\text { para resolver os problemas por eles mesmos. Pareceu não haver uma } \\
\text { preocupação em esgotar o conteúdo no tempo da aula. Apesar de o }\end{array}$ & 30 & ALTA \\
\hline
\end{tabular}




\begin{tabular}{|c|c|c|c|}
\hline Máximo: 28 a 36 & $\begin{array}{l}\text { número de alunos ser inadequado (sala muito cheia), a organização } \\
\text { da turma foi adequada para o processo instrucional pretendido. Fez } \\
\text { uso de materiais manipulativos concretos que permitiram introduzir } \\
\text { boas situações, linguagens, procedimentos, argumentações } \\
\text { adaptadas ao conteúdo. }\end{array}$ & & \\
\hline $\begin{array}{l}\text { Idoneidade } \\
\text { Interacional } \\
\text { Escore (Niveis): } \\
\text { Mínimo: } 7 \text { a } 21 \\
\text { Médio: } 28 \text { a } 42 \\
\text { Máximo: } 49 \text { a } 63\end{array}$ & $\begin{array}{l}\text { Reconheceu e resolveu com frequência os conflitos dos alunos (fez } \\
\text { perguntas e respostas adequadas etc.). Fez uso de recursos retóricos } \\
\text { e argumentativos para implicar e captar a atenção dos alunos, } \\
\text { facilitando a inclusão dos mesmos na dinâmica da classe. Favoreceu } \\
\text { o diálogo e comunicação entre os estudantes. Tratou de convencer a } \\
\text { si mesmo e aos demais da validade de suas afirmações, conjecturas } \\
\text { e respostas, apoiando-se em argumentos matemáticos. Incentivou a } \\
\text { inclusão no grupo e contemplou momentos em que os estudantes } \\
\text { assumiram a responsabilidade do estudo. Explorou exemplos e } \\
\text { contraexemplos para investigar e conjecturar, usando algumas } \\
\text { ferramentas para pensar, estabelecer conexões, resolver problemas } \\
\text { e comunicá-los. }\end{array}$ & 63 & ALTA \\
\hline $\begin{array}{l}\text { Idoneidade } \\
\text { Afetivo- } \\
\text { emocional } \\
\text { Mínimo: } 5 \text { a } 35 \\
\text { Médio: } 10 \text { a } 40 \\
\text { Máximo: } 35 \text { a } 45\end{array}$ & $\begin{array}{l}\text { A professora pouco propôs situações para valorizar a utilidade da } \\
\text { Matemática na vida cotidiana e profissional, entretanto as tarefas } \\
\text { quase sempre despertaram o interesse dos alunos. Estimulou a } \\
\text { participação dos alunos nas atividades, à perseverança e } \\
\text { responsabilidade. Por se dar conta dos estados emocionais, foi } \\
\text { frequente a promoção da autoestima para criar gosto pela Matemática } \\
\text { ensinada. Valorizou moderadamente a qualidade de estética e } \\
\text { precisão da Matemática. }\end{array}$ & 33 & $\begin{array}{l}\text { Transição } \\
\text { entre } \quad 0 \\
\text { MÉDIO e } 0 \\
\text { ALTO }\end{array}$ \\
\hline $\begin{array}{l}\text { Idoneidade } \\
\text { Ecológica } \\
\text { Mínimo: } 5 \text { a } 35 \\
\text { Médio: } 10 \text { a } 40 \\
\text { Máximo: } 35 \text { a } 45\end{array}$ & $\begin{array}{l}\text { Os conteúdos se relacionaram com outros conteúdos } \\
\text { intradisciplinares. Foi nítida a contemplação de valores democráticos } \\
\text { e o pensamento crítico, entretanto a forma abordada pouco contribuiu } \\
\text { na formação socioprofissional dos estudantes. Não houve integração } \\
\text { de novas tecnologias (calculadoras, computadores, TIC etc.), no } \\
\text { projeto educativo. Os conteúdos, sua implementação e a avaliação } \\
\text { corresponderam com as diretrizes curriculares. }\end{array}$ & 27 & MÉDIA \\
\hline
\end{tabular}

Fonte: Amorim (2017) a partir dos Critérios de Idoneidade Didática

Figura 5: Gráficos comparativos das Idoneidades Didáticas das práticas observadas

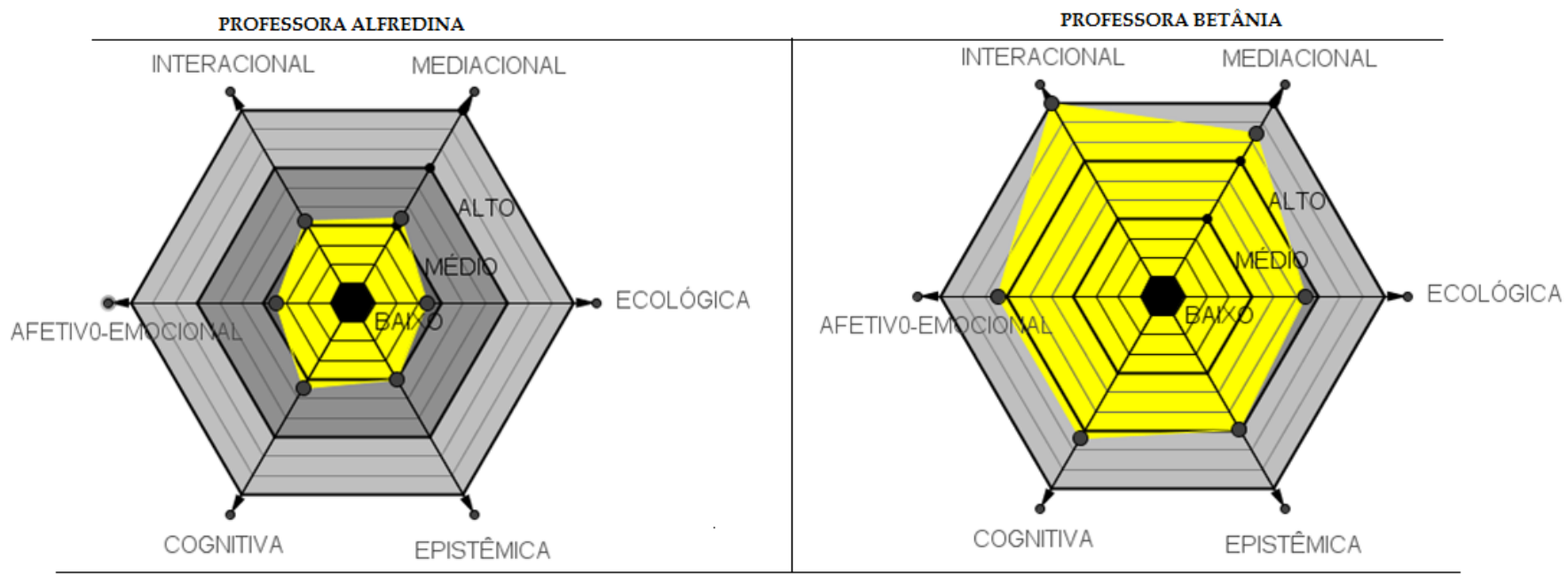

Fonte: Godino (2011). Redesenho Amorim (2017) 


\section{Considerações Finais}

Em sala de aula, durante muito tempo, perpetuou a ideia de que 0 aluno deveria segregar os aspectos cognitivos dos afetivos para que a aprendizagem fluísse. Os desejos, seus sentimentos e emoções deveriam ser descartados do processo de ensino e de aprendizagem. (AMORIM, 2017; AMORIM e GUSMÃO, 2010; GUSMÃO, DÓRIA e SILVA, 2019). Dessa forma, era necessário que os educadores ignorassem a necessidade do diálogo, os silêncios, os rubores das faces, os suspiros, tremores, dentre outros indicadores da presença de emoção. Apenas o conteúdo e as inteligências eram valorizados em sala de aula. (JARDIM, 2015)

Mesmo depois de muitos estudos científicos e reflexões realizados sobre essa temática, esse pensamento, em sala de aula, ainda não desapareceu por completo. Na análise da prática matemática da professora Alfredina, percebemos que as exposições do conteúdo foram supervalorizadas, em detrimento ao conhecimento subjetivo dos educandos. Mesmo considerando bom seu relacionamento com a turma, a pesquisa, a partir das categorias delimitadas, apontou como baixa a Idoneidade AfetivoEmocional presente na prática matemática da professora citada.

Podemos perceber que os estudantes, durante as aulas de Matemática, são estimulados constantemente e, a partir das suas crenças, reagem emocionalmente. Quando estas reações satisfação, frustração etc. - passam a se repetir com constância, poderão se tornar automatizadas, transformando-se em atitudes (CHACÓN, 2003). Ao afirmar, no preenchimento do questionário, que não percebia nenhum tipo de emoções relevantes em seus alunos, exceto em momentos de avaliação, Alfredina revelou o completo desconhecimento das implicações que os fatores emocionais podem acarretar em sua prática matemática e no momento avaliativo.

Além disso, as idoneidades ecológica e mediacional também obtiveram notas baixas em virtudes da falta de contextualização intra e interdisciplinar, agravado com a falta da inovação de recursos que assegurem a motivação e a persistência de seus alunos frente aos problemas matemáticos.

O que Alfredina não compreendia é que há uma estreita relação entre contextos e tarefas, visto que uma situação rica de aprendizagem é um panorama ideal para apresentar uma Matemática capaz de estimular a atividade do aluno, ao passo em que proporcione reflexões sobre a realidade social mais ampla (SOUSA et al, 2019). As situações contextualizadas são o ponto crucial da ligação entre o mundo da Matemática e o mundo material/físico.

Diferentemente da professora Alfredina, a professora Betânia reconheceu e resolveu os conflitos dos alunos; empreendeu atividades motivadoras, incentivando-os a refletir sobre seus pensamentos e raciocínio; priorizou o diálogo, a comunicação entre os estudantes; favoreceu a autonomia e confiança. 
Além de procurar novos meios para enriquecer sua aula, Betânia estabeleceu em sua prática a conexão intramatemática, ao utilizar a Geometria como suporte; e reforçou para seus alunos a importância de se aprender o conteúdo abordado.

Consequentemente, numa análise geral, percebemos que enquanto a avaliação da prática matemática de Alfredina concentrou-se na região que corresponde ao nível baixo, a de Betânia expandiu do escore máximo do nível médio até o nível alto.

Entretanto, assim como Alfredina, Betânia quase não explorou situações-problema. Nesse sentido, Godino, Contreras e Font (2006) destacam a necessidade do trabalho com situações problema, como geradora de superação de dificuldade, provocando aprendizagem matemática. As situaçõesproblema devem empreender desafios geradores com intuito de desestabilizar as estruturas afetiva e cognitiva, motivando a criança a superar as dificuldades propostas, e, assim, realizando atividades matemáticas. As emoções estariam associadas à reorganização do sistema cognitivo a partir desses conflitos.

Em suma, na análise das duas práticas matemáticas, percebemos que quanto mais o professor empreende atividades motivadoras com situações-problema; incentiva o diálogo entre os estudantes e docente e concebe o erro como processo de aprendizagem, maior será o grau da Idoneidade Didática de sua prática matemática, estimulando a autonomia, a confiança e a perseverança dos alunos e levando a refletirem sobre seus pensamentos e raciocínio.

Logo a dificuldade é necessária para a aprendizagem. Porém, como já salientou Brousseau (1986), essa dificuldade, ou obstáculo, não pode se tornar um paralisador da aprendizagem para a criança.

Assim, um dos desafios que se coloca à Escola contemporânea é o de educar e formar uma pluralidade de alunos, no sentido sociocultural, emocional e cognitivo. Mas como avaliar a atenção dada à dimensão emocional pelo professor em sua prática matemática? Percebemos com o presente estudo que os Critérios de Idoneidade Didática, proposto pelo Enfoque Ontossemiótico, permitem-nos desenvolver tal avaliação, bem como a possibilidade de relacioná-la às dimensões cognitiva, interacional, ecológica, mediacional e epistêmica.

Como os aspectos emocionais apresentam uma estreita relação com o sucesso escolar, os professores poderiam voltar seus esforços na adequação e integração das dimensões idôneas propostas pelos CID, com o intuito de otimizar o potencial dos alunos para serem bem sucedidos na escola e ao longo da vida. Dessa forma, entendemos que, na medida em que aumenta a compreensão dos professores sobre os efeitos do contexto emocional, cognitivo, epistêmico, interacional, mediacional e 
ecológico, no processo educativo de jovens, mais o âmbito educacional se constituirá como espaço privilegiado na promoção do desenvolvimento integral do aluno, assim como defendia Wallon (1995).

Acreditamos que o estudo realizado cumpriu seu papel de oferecer novos subsídios para área de estudos matemáticos, uma vez que não encontramos, no banco de dissertações e teses da CAPES, pesquisas que relacionam a questão emocional com a teoria proposta pelos EOS. Nesse sentido, a pesquisa apresenta novos olhares e novas perspectivas sobre o Ensino da Matemática e oferece considerável contribuição para que os próprios professores possam dar mais atenção a variável afetiva/emocional em sala de aula.

\section{Referências}

AMORIM, Luciana Correia. $A$ atenção dada às Emoções na sala de aula pelo professor de Matemática: contribuições dos Critérios de Idoneidade Didática. Jequié, BA, 2017. Dissertação (Mestrado em Educação Científica e Formação de Professores - Universidade Estadual do Sudoeste da Bahia, Jequié.

AMORIM, Luciana Correia; FONT, Vicenç; GUSMÃO, Tânia Cristina Rocha Silva. Critérios de Idoneidade Didática: Uma análise das Emoções em Práticas Matemáticas. In: FARIAS, Luiz Márcio Santos; CAMPOS, Márcia Azevedo Campos (org.). Elementos da didática das ciências na perseverança e superação escolar. 1 ed. Salvador: EDUFBA, 2021, p.49-63.

AMORIM, Luciana Correia; FONT, Vicenç; GUSMÃO, Tânia Cristina Rocha Silva. Uma análise das emoções em práticas matemáticas a partir dos Critérios de Idoneidade Didática. In: SEGUNDO CONGRESO INTERNATIONAL VIRTUAL SOBRE EL ENFOQUE ONTOSEMIÓTICO DEL CONOCIMIENTO Y LA INSTRUCCIÓN MATEMÁTICOS. Actas del $2^{\circ}$ CIVEOS. 2017. Disponível em: http://enfoqueontosemiotico.ugr.es/civeos/amorim.pdf. Acesso em 09/02/2021.

AMORIM, Luciana Correia; GUSMÃO, Tânia Cristina Rocha Silva. Matemática e emoções: Um diálogo com professores da Educação Básica. In: DÉCIMO COLÓQUIO NACIONAL E TERCEIRO COLÓQUIO INTERNACIONAL DO MUSEU PEDAGÓGICO. Anais do $10^{\circ} \mathrm{CNMP}$, Vitória da Conquista. Universidade Estadual do Sudoeste da Bahia, 2013.

BOGDAN, Robert; BIKLEN, Sari Knopp. Investigação qualitativa em educação: uma introdução à teoria e aos métodos. Porto: Codex Porto, 1994.

BRASIL. Ministério da Educação. Base Nacional Comum Curricular - Documento preliminar. MEC. Brasília, DF, 2015.

BRASIL. Secretaria de Educação Fundamental. Parâmetros curriculares nacionais: Matemática / Secretaria de Educação Fundamental. Brasília : MEC / SEF, 1998

BREDA, Adriana; FONT, Vicent; LIMA, Valderez Marina do Rosário. A. Noção de idoneidade didática e seu uso na formação de professores de matemática. Jornal Internacional de Estudos em Educação Matemática. v. 8, n. 2, 2015. 
BROUSSEAU, Guy. Fondements et Méthodes de la Didactique des Mathématiques. Recherches em Didactique des Mathématiques, Grenoble, v. 7, n. 2, p. 33-116, 1986.

CHACÓN, Inés Maria Gomes. Matemática Emocional: os afetos na aprendizagem matemática. Porto Alegre: Artmed. 2003.

CHIZZOTTI, Antônio. Pesquisas Qualitativas em Ciências Humanas e Sociais. Petrópolis, R.J.: Vozes, 2008.

CODO, Wanderley; MENEZES, lône Vasques. Educar, Educador. In: CODO, Wanderley (org.). Educação: carinho e trabalho. 3 ed. Vozes/Brasília: CNTE: Universidade de Brasília. Laboratório de Psicologia do Trabalho, 1999, p. 37-47.

GODINO, Juan Díaz. Indicadores de la idoneidad didáctica de procesos de enseñanza y aprendizaje de las matemáticas. Cuadernos de Investigación y Formación en Educación Matemática, v.11, p.111132. 2013.

GODINO, Juan Díaz. Indicadores de la idoneidad didáctica de procesos de enseñanza y aprendizaje de las matemáticas. In: DÉCIMA TERCEIRA CONFERÊNCIA INTERAMERICANA DE EDUCAÇÃO MATEMÁTICA. Anais da $13^{\mathrm{a}}$ CIAEM-IACME, Recife, Brasil, 2011. Disponível em: https://www.ugr.es/ igodino/eos/jdgodino indicadores_idoneidad.pdf. Acesso em 23/05/2021

GODINO, Juan Díaz. De la ingeniería a la idoneidad didáctica en educación matemática. Revemop, v. 3, p. e202129, 2021. DOI: https://periodicos.ufop.br/revemop/article/view/5066/3833. Acesso em $19 / 09 / 2021$

GODINO, Juan Díaz; BATANERO, Carmen; FONT, Vicenç. The onto-semiotic approach to research in mathematics education. ZDM. The International Journal on Mathematics Education, v. 39, n. 1-2, p. 127-135. 2007. Disponivel em: https://www.ugr.es/ igodino/funcionessemioticas/ontosemiotic approach.pdf . Acesso em 09/02/2021.

GODINO, Juan Díaz; CONTRERAS, Angel; FONT, Vicenç. Análisis de procesos de instrucción basado en el enfoque ontológico-semiótico de la cognición matemática. Recherches en Didactique des Mathématiques, v.. 26, n.1, p. 39-88, 2006.

GODINO, Juan Díaz; FONT, Vicent; WILHELMI, Miguel Rodriguez; CASTRO, Carlos de. Aproximación a la dimensión normativa en Didáctica de la Matemática desde un enfoque ontosemiótico. Enseñanza de las Ciencias, n. 27, v.1, p. 59-76, 2009.

GODINO, Juan Díaz; BATANERO, Carmen; RIVAS, Hernán; ARTEAGA, Pedro. Componentes e indicadores de idoneidad de programas de formación de profesores en didáctica de las matemáticas. REVEMAT, Florianópolis (SC), v. 08, n. 1, p. 46-74, 2013.

GUSMÃO, Tânia Cristina Rocha Silva. Em cartaz: razão e emoção na sala de aula. 1 ed. Salvador: Edições UESB, 2010.

GUSMÃO, Tânia Cristina Rocha Silva; DÓRIA, Mariluce Cidade França; SILVA, José Eduardo Rocha. Percepções e reações de professores e alunos frente às emoções na aula de matemática. Revista Binacional Brasil Argentina, Vitória da Conquista, v. 8, n.2, p. 95-109, dez. 2019.

GUSMÃO, Tânia Cristina Rocha Silva; EMERIQUE, Paulo Sérgio. Do Erro Construtivo ao Erro Epistemológico: um espaço para as emoções. Bolema. Ano 13, n. 14, p. 51-65, 2000. 
JARDIM, Rosângela de Souza Meurer. Aprendizagem com afeto: Uma contribuição da Neurociência Pedagógica. Monografia (Especialiação em Neurociência Pedagógica). Universidade Cândido Mendes. Rio de Janeiro, 2015.2 Disponível em: https://www.avm.edu.br/docpdf/monografias_publicadas/C208399.pdf. Acesso em: 05 ago. de 2020.

LAKOMI, Ana Maria. Teorias cognitivas da aprendizagem. 2 ed. Curitiba: Ibpex, 2008.

LÜDKE, Menga.; ANDRÉ, Marli Eliza Dalmazo Afonso. Pesquisa em educação: abordagens qualitativas. São Paulo, Editora Pedagógica e Universitária, 1986.

MELO, P. Produtos Notáveis. Disponivel em:< http://www.estudopratico.com.br/produtos-notaveisdefinicao-tipos-de-produtose-exemplos>. Acesso em: 05 ago. de 2016.

MOREIRA, C. B; GUSMÃO, Tânia Cristina Rocha Silva; FONT, Vicenç. Tarefas Matemáticas para o Desenvolvimento da Percepção de Espaço na Educação Infantil: potencialidades e limites. Bolema, Rio Claro (SP), v. 32, n. 60, p. 231 - 254, abr. 2018.

RÊGO; Claudia Carla de Azevedo Brunelli.; ROCHA, Nívea Maria Fraga. Avaliando a educação emocional: subsídios para um repensar da sala de aula. Ensaio: Avaliação e Políticas Públicas em Educacção, Rio de Janeiro, v. 17, n. 62, p. 135-152, jan./mar. 2009. Disponível em: http:/l https://www.scielo.br///ensaio/a/zWCR5qbZpNhwY8TXHVHshzf/?lang=pt\&format=pdf. Acesso em 09/02/2021.

SOUSA, Jorge Ramos de; FONT, Vicenç; GUSMÃO, Tânia Cristina Rocha Silva; ROSEIRA, Nilson Antonio Ferreira. Contribuições do (re)desenho de tarefas para aproximação da matemática com o entorno social da escola. Revista Práxis Educacional, Vitória da Conquista - Bahia - Brasil, v. 15, n. 33, p. 444-471, jul./set. 2019.

WALLON, Henri. As origens do caráter na criança. São Paulo: Nova Alexandria, 1995. 